\title{
Ractopamine hydrochloride in formulated rations for barrows or gilts from 94 to $130 \mathrm{~kg}^{1}$
}

\author{
Nikolas de Oliveira Amaral ${ }^{2}$, Elias Tadeu Fialho ${ }^{2}$, Vinícius de Souza Cantarelli ${ }^{2}$, Márcio \\ Gilberto Zangeronimo², Paulo Borges Rodrigues ${ }^{2}$, Lúcio Vilela Carneiro Girão ${ }^{3}$
}

\footnotetext{
1 Pesquisa financiada pela FAPEMIG.

2 Departamento de Zootecnia, DZO - UFLA.

${ }^{3}$ Departamento de Zootecnia, UNESP - Botucatu.
}

ABSTRACT - An experiment was carried out to evaluate the performance, carcass composition, cutting yields and economic viability of 5 or $10 \mathrm{ppm}$ of ractopamine hydrochloride (RAC) in diets for barrows and gilts from 94 to $130 \mathrm{~kg}$. Sixty commercial hybrid pigs within a gender, were individually kept in pens and assigned a randomized experimental block design, in a $3 \times 2$ factorial arrangement, with three levels of RAC (0; 5 and $10 \mathrm{ppm})$ and two sexs (barrows and gilts). There were no RAC $\times$ sex interactions for all evaluated parameters. There were significant improvements for the groups of RACtreated on final weight, average daily gain (ADG) and feed:gain (F:G). The RAC, independent from the level (5 or 10 ppm), improved the F:G, but did not influence the average feed intake. The gilts had smaller final weight, smaller average feed intake and better F:G. The supplementation with $10 \mathrm{ppm}$ of RAC provided better carcass yield, better longissimus muscle area and better meat percentage. The pigs supplemented with RAC showed better tenderloin yield, better ham weight and better meat percentage of ham. The gilts had better meat percentage, better back fat thickness, bigger belly flexibility and smaller fat thickness of the belly than barrows. On economic viability, the RAC-treated pigs increased the allowance index, gross earnings and net earnings. Compared to the barrows, gilts showed lower total cost, better allowance index and higher net earnings. The supplementation with 5 ppm of RAC was enough to improve performance, carcass composition and cutting yields in the heavy pigs. Furthermore, 5 or 10 ppm of RAC was economically viable and the heavy gilts were more profitable than heavy barrows.

Key Words: additive, carcass modifier, lean meat, nutrition, performance

\section{Cloridrato de ractopamina em rações formuladas para suínos machos castrados ou para fêmeas na fase dos 94 aos $130 \mathrm{~kg}$}

\footnotetext{
RESUMO - Foi realizado um experimento com o objetivo de avaliar o desempenho, a composição de carcaça e a viabilidade econômica do uso de 5 e $10 \mathrm{ppm}$ de cloridrato de ractopamina (RAC) em rações formuladas para suínos machos castrados ou para fêmeas dos 94 aos $130 \mathrm{~kg}$. Utilizaram-se 60 suínos, distribuídos em delineamento de blocos ao acaso, em arranjo fatorial $3 \times 2$, composto de três níveis de ractopamina e dois sexos. Não houve interação significativa entre a ractopamina e o sexo para as variáveis analisadas. Observou-se, nos animais que receberam ractopamina, maior peso final, ganho de peso médio diário e conversão alimentar. As fêmeas apresentaram menor peso final, consumo médio diário de ração e conversão alimentar. Para rendimento de carcaça, área de olho-de-lombo e rendimento de carne na carcaça, o nível de $10 \mathrm{ppm}$ foi superior ao controle. A ractopamina, independentemente do nível utilizado, reduziu a espessura de toucinho e melhorou o rendimento de filezinho, pernil e carne no pernil. As fêmeas apresentaram maior rendimento de carne na carcaça, menor espessura de toucinho, maior flexibilidade da barriga e menor espessura de toucinho da barriga. As carcaças de suínos sob suplementação com ractopamina apresentaram melhor índice de bonificação, receita bruta e receita líquida. Houve redução no custo total e aumento no índice de bonificação das carcaças das fêmeas, o que melhorou a receita líquida. Dessa forma, a suplementação com 5 ppm de ractopamina é suficiente para melhorar o desempenho, a composição de carcaça e o rendimento de cortes da carcaça de suínos machos castrados e fêmeas. Além disso, a suplementação com 5 ou 10 ppm de ractopamina, nas condições estudadas, é economicamente viável, e o abate de fêmeas aos $130 \mathrm{~kg}$, mais rentável que o de machos castrados.
}

Palavras-chave: aditivos, carne magra, desempenho, modificador de carcaça, nutrição 


\section{Introduction}

The current pig production chain has given emphasis on improving the carcass quality of slaughtered animals to meet consumer demand for pork. Moreover, slaughterhouses tend to give better evaluations to heavy carcasses with greater meat proportion, thus enhancing the importance of quality in the pork supply chain.

Furthermore, with an increase in body weight, pigs have a higher capacity of feed intake, which results in lower feed efficiency and, consequently, accumulation of body fat (Latorre et al., 2004). Thus, programs of genetic selection, feed management and nutritional resources have been developed in recent years in order to allow the future slaughter of these animals without compromising performance and carcass quality (Arouca et al., 2007).

In nutrition, ractopamine (RAC), which was associated with inhibition of lipogenesis, increased lipolytic activity and muscle synthesis (Aalhus et al., 1992; Engeseth et al., 1992), and has been broadly used in pig diet formulation. Some studies have shown that ractopamine improves performance and animal carcass characteristics, regardless the slaughter weight (Silveira et al., 2005; Weber et al., 2006).

In addition, gender is a major factor in determining the potential of growth, voluntary feed intake, feed efficiency and pig carcass quality in the growing and finishing period (Henry et al., 1992). Thus, diet formulation should be seen as a production strategy, since there are variations in growth potential between genders. The required nutritional levels differ for barrows and gilts, and pigs may show different responses to the use of ractopamine in the diet according to gender, justifying the use of diets formulated separately for each sex.

This research evaluates the economic viability of using either 5 or $10 \mathrm{ppm}$ of ractopamine hydrochloride in the diets of barrows and gilts ranging from 94 to $130 \mathrm{~kg}$. Slaughtered pigs were evaluated by performance and carcass condition to meet the evolving needs of modern consumers.

\section{Material and Methods}

The experiment was carried out in the Departamento de Zootecnia of Universidade Federal de Lavras (UFLA), Lavras, in southern Minas Gerais, from April to June 2007.

A total of 60 finishing hybrid pigs (30 barrows and 30 gilts) with high deposition of lean meat, were selected from a commercial farm located in Oliveira, Minas Gerais. Pigs had initial weight of $93.8 \mathrm{~kg} \pm 2.2 \mathrm{~kg}$ and an average final weight of $129.06 \mathrm{~kg}$. The animals were individually housed in experimental plots with $(2.3 \times 1.5 \mathrm{~m})$ concrete-floor pens and semi-automatic feeders. All pigs were provided with ad libitum access to feed and water.

The experimental design was in randomized blocks $3 \times 2$ factorial arrangement with three levels of ractopamine $(0,5$ or $10 \mathrm{ppm})$ and two genders (barrows or gilt), totaling six treatments and ten replications with one animal per experimental plot. The criteria for the block formations were determined when the animals reached an average weight of $93.8 \mathrm{~kg}$.

The experimental diets were formulated based on corn and soybean meal and supplemented with vitamins, minerals and amino acids, following the minimum recommendations suggested by Rostagno et al. (2005) for barrows from 100 to $120 \mathrm{~kg}$, with an increase in the levels of metabolizable energy (ME), crude protein (CP) and lysine in diets formulated for gilts.

According to Mitchell et al. (1990) and Xiao et al. (1999), animals under supplementation with ractopamine achieve significant increases in performance and carcass quality, when the minimum diet of $16 \% \mathrm{CP}$ and $30 \%$ more of total lysine was received. Thus, the diets were formulated to provide $1.00 \%$ total lysine for barrows (16\% CP) and $1.04 \%$ total lysine for gilts (17\% CP), adjusting the amounts of methionine and threonine to achieve the ideal profile in relation to lysine content (Table 1 ).

The diets were given ad libitum during the 28 day trial period. The pigs were weighed at the beginning and the end of the experiment to determinate the weight gain. The stalls were cleaned daily, while ration and waste were weighed twice daily to determine the consumption of each animal. Feed: gain $(F: G)$ was obtained by the relation between feed intake and weight gain in this period.

After 28 days of supplementation with ractopamine, the animals were subjected to fasting solids for a 12 hour period; then all were weighed, slaughtered and eviscerated for carcasses evaluation. Immediately after evisceration, the carcasses were split in half lengthwise and weighed. The left half carcass of each pig was cooled to a $7^{\circ} \mathrm{C}$ during 24 hours for further characteristics evaluation. All measurements were made according to the Brazilian Method for Carcass Evaluation (ABCS, 1973).

The carcass yield, longissimus muscle area, backfat thickness and estimated percentage of meat in the carcass by prediction analysis, were evaluated according to the formula described by Guidoni (2000):

MPCC $=65.92-(0.685 \times \mathrm{BT})+(0.094 \times \mathrm{DL})-(0.026 \times \mathrm{HCW})$ where: MPCC: meat percentage in the cooled carcass (\%); BT: backfat thickness; DL: depth of loin; HCW: hot carcass weight.

To assess the quality of the belly/bacon and yield of cuts, the belly yield, backfat thickness, belly flexibility, ham 
Table 1 - Composition of the experimental diets

Ractopamine level (ppm)

\begin{tabular}{|c|c|c|c|c|c|c|}
\hline \multirow[t]{2}{*}{ Ingredient (\%) } & \multicolumn{3}{|c|}{ Barrow } & \multicolumn{3}{|c|}{ Gilt } \\
\hline & 0 & 5 & 10 & 0 & 5 & 10 \\
\hline Corn & 76.85 & 76.83 & 76.80 & 72.40 & 72.37 & 72.35 \\
\hline Soybean meal & 21.00 & 21.00 & 21.00 & 24.00 & 24.00 & 24.00 \\
\hline Soybean oil & 0.000 & 0.000 & 0.000 & 1.500 & 1.500 & 1.500 \\
\hline L-Lysine-HCl 78\% & 0.235 & 0.235 & 0.235 & 0.200 & 0.200 & 0.200 \\
\hline DL-Methionine 99\% & 0.020 & 0.020 & 0.020 & 0.020 & 0.020 & 0.020 \\
\hline L-Threonine $98,5 \%$ & 0.055 & 0.055 & 0.055 & 0.045 & 0.045 & 0.045 \\
\hline Dicalcium phosphate & 0.800 & 0.800 & 0.800 & 0.800 & 0.800 & 0.800 \\
\hline Limestone & 0.500 & 0.500 & 0.500 & 0.500 & 0.500 & 0.500 \\
\hline Salt & 0.300 & 0.300 & 0.300 & 0.300 & 0.300 & 0.300 \\
\hline Mineral $\operatorname{mix}^{1}$ & 0.100 & 0.100 & 0.100 & 0.100 & 0.100 & 0.100 \\
\hline Vitamin $\operatorname{mix}^{2}$ & 0.100 & 0.100 & 0.100 & 0.100 & 0.100 & 0.100 \\
\hline Tylan $-250^{3}$ & 0.100 & 0.100 & 0.100 & 0.100 & 0.100 & 0.100 \\
\hline Paylean $^{4}$ & 0.000 & 0.025 & 0.050 & 0.000 & 0.025 & 0.050 \\
\hline \multicolumn{7}{|l|}{ Nutricional (calculated) } \\
\hline Crude protein (\%) & 16.05 & 16.05 & 16.05 & 17.03 & 17.03 & 17.03 \\
\hline Metabolizable energy (kcal/kg) & 3230 & 3230 & 3230 & 3300 & 3300 & 3300 \\
\hline Total lysine $(\%)$ & 1.00 & 1.00 & 1.00 & 1.04 & 1.04 & 1.04 \\
\hline Digestible lysine (\%) & 0.842 & 0.842 & 0.842 & 0.885 & 0.885 & 0.885 \\
\hline Digestible methionine (\%) & 0.259 & 0.259 & 0.259 & 0.270 & 0.270 & 0.270 \\
\hline Digestible threonine (\%) & 0.58 & 0.58 & 0.58 & 0.605 & 0.605 & 0.605 \\
\hline Available phosphorus (\%) & 0.245 & 0.245 & 0.245 & 0.249 & 0.249 & 0.249 \\
\hline Calcium $(\%)$ & 0.461 & 0.461 & 0.461 & 0.467 & 0.467 & 0.467 \\
\hline Ractopamine (ppm) & 0.0 & 5.0 & 10.0 & 0.0 & 5.0 & 10.0 \\
\hline
\end{tabular}

yield, ham weight, meat percentage of ham, and tenderloin yield were analyzed (Rentfrowa et al., 2003).

The economic viability of ractopamine supplementation was also evaluated. The carcass allowance index, crude earnings, total cost and net earnings were also evaluated. The crude earnings (CE) within the classification system were determined based on the allowance index (AI), as described by Guidoni (2000), based on the carcass yield average (82.56kg) and the HCW, using the following formula: $\mathrm{CE}=(\mathrm{AI} *[$ price $/ \mathrm{kg}$ of finished pig / 0.8256] $) * \mathrm{HCW}$

Based on the final pig price and diet ingredient price obtained in Lavras, Minas Gerais, in January of 2008 (Table 2), feed costs (FC) were determined during the experimental period; the cost of the pig initial weight (PIWC), the total cost (TC) and net earnings (NE), where calculated according by Cantarelli (2007):

$\mathrm{FC}=$ total feed intake*diet cost

PIWC $=$ animal weight* price $/ \mathrm{kg}$ of finished pig

$\mathrm{TC}=\mathrm{FC}+\mathrm{PIWC}$

$\mathrm{NE}=\mathrm{CE}-\mathrm{TC}$

Data were submitted to covariance analysis using the initial weight of the animals as the covariate. The F test
Table 2 - Price of diet ingredients and finished pigs in January of 2008, recorded in Lavras, Minas Gerais

\begin{tabular}{lc}
\hline Ingredient $(\mathrm{kg})$ & Cost US\$/kg \\
\hline Corn & 0.28 \\
Soybean meal & 0.34 \\
Soybean oil & 1.22 \\
L-lysine-HCl 78\% & 2.50 \\
DL-methionine 99\% & 4.25 \\
L-threonine 98,5\% & 3.51 \\
Dicalcium phosphate & 0.60 \\
Limestone & 0.02 \\
Salt & 0.12 \\
Mineral mix & 1.57 \\
Vitamin mix & 5.77 \\
Tylan 250® & 35.39 \\
Paylean & ${ }^{\circledR}$ \\
Finished pig & 40.34 \\
\hline
\end{tabular}

was used to compare gender and the Tukey test at 5\% was employed for comparing levels of ractopamine, alone or in interaction, when significant. Statistical analysis was conducted using the GLM procedure of SAS (1996). 


\section{Results and Discussion}

Similarly to the results obtained by Dunshea et al. (1993) and Uttaro et al. (1993), the interaction between the use of ractopamine and sex was not significant $(\mathrm{P}>0.05)$ for the final weight, the average daily gain, the average daily feed intake and the feed: gain ratio (Table 3 ).

Pigs receiving ractopamine had higher final weight, higher average daily gain and a lower feed: gain ratio $(\mathrm{P}<0.05)$. This showed that the use of the additive had a positive influence on pig performance for both genders. Ractopamine, regardless the level used (5 or $10 \mathrm{ppm}$ ), improved $(\mathrm{P}<0.05)$ the feed: gain of animals in $13.46 \%$, final weight in $2.32 \%$ and daily gain average of $8.4 \%$. Moreover, the improvement in feed efficiency for animals that received ractopamine was not related by the reduction in feed intake.

Results presented here are similar to those reported by Crome et al. (1996), who studied the influence of two slaughter weights (107 and $125 \mathrm{~kg}$ ) and three levels of ractopamine (0,10 and $20 \mathrm{ppm})$. Crome et al. observed that ractopamine improved performance of finishing pigs, regardless the weight; however, the authors also observed reductions in feed intake corresponding to the increases observed in the aforementioned variables.

Several other authors have demonstrated the effect of ractopamine in increasing the final weight (Armstrong et al., 2004, Carr et al., 2005a, Weber et al., 2006 and Xiong et al., 2006) and average daily gain of animals (Adeola et al., 1990, Watkins et al., 1990, Gu et al., 1991; Crome et al., 1996 and Marinho et al., 2007). However, variable performance shows great consistency in experiments using ractopamine in the feed, since it may be related to the effect of ractopamine in the feed intake reduction (Mitchell et al., 1990; Adeola et al., 1990; Yen et al., 1990) and an increase in weight gain (Zagury, 2002; Cantarelli, 2007). Moreover, in some experiments, no effects were observed in final weight (Schinckel et al., 2003; Mimbs et al., 2005; Carr et al., 2005b) or average daily gain for ractopamine fed pigs (Yen et al., 1990; Aalhus et al., 1990; Mimbs et al., 2005, Carr et al., 2005b). According to Dunshea et al. (1993), the interaction among ractopamine, genotype and nutritional management explains this variability in results.

According to Schinkel et al. (2003), the improvement observed in finishing pig performance may result from the effect that ractopamine has on the animal body through the change of metabolism, with increased protein synthesis and lipogenesis blockade. This is because the increase in protein deposition requires energy expenditure that is three times lower when compared to the adipose tissue synthesis (English et al., 1988). Consequently, there is a change in the
Table 3 - Performance of barrows and gilts fed diets supplemented with ractopamine

\begin{tabular}{lcccc}
\hline \multirow{2}{*}{ Item } & \multicolumn{3}{c}{ Ractopamine level (ppm) } & \multirow{2}{*}{ Mean $^{1}$} \\
\cline { 2 - 4 } & 0 & 5 & 10 & \\
\hline Initial weight (kg) & & & & \\
Barrow & 94.16 & 94.34 & 95.12 & 94.54 \\
Gilt & 93.22 & 92.81 & 93.56 & 93.20 \\
Mean $^{1}$ & 93.69 & 93.58 & 94.34 & 93.87 \\
Final weight (kg) & & & & \\
Barrow & & & & \\
Gilt & 127.19 & 131.63 & 131.92 & $130.24 \mathrm{~A}$ \\
Mean ${ }^{1}$ & 127.00 & 127.67 & 128.97 & $127.88 \mathrm{~B}$ \\
CV (\%) & $127.09 \mathrm{~b}$ & $129.65 \mathrm{a}$ & $130.45 \mathrm{a}$ & 129.06 \\
& 3.06 & & & \\
& & & &
\end{tabular}

Average daily gain $(\mathrm{kg})$

$\begin{array}{lclll}\text { Barrow } & 1.180 & 1.332 & 1.314 & 1.275 \\ \text { Gilt } & 1.21 & 1.245 & 1.265 & 1.239 \\ \text { Mean }^{1} & 1.193 \mathrm{~b} & 1.288 \mathrm{a} & 1.289 \mathrm{a} & 1.257 \\ \text { CV }(\%) & 9.55 & & & \end{array}$

Average daily feed intake (kg)

\begin{tabular}{lrlll} 
Barrow & 4.17 & 4.07 & 4.09 & $4.11 \mathrm{~A}$ \\
Gilt & 3.88 & 3.37 & 3.56 & $3.60 \mathrm{~B}$ \\
Mean $^{1}$ & 4.02 & 3.72 & 3.83 & 3.86 \\
CV (\%) & 10.78 & & & \\
Feed:gain & & & & \\
Barrow & & & & \\
Gilt & 3.55 & 3.07 & 3.12 & $3.24 \mathrm{~A}$ \\
Mean $^{1}$ & 3.22 & 2.71 & 2.84 & $2.92 \mathrm{~B}$ \\
CV $(\%)$ & $3.38 \mathrm{a}$ & $2.88 \mathrm{~b}$ & $2.97 \mathrm{~b}$ & 3.08 \\
\hline
\end{tabular}

${ }^{1}$ Means followed by different small letters in the row and capital letters in the column differ by Tukey test $(\mathrm{P}<0.05)$.

animal gain composition, which deposit more muscle and less fat.

Regarding the level of use of ractopamine, the results of performance were consistent with those described by Schinkel et al. (2001), who reported that most of the responses to ractopamine can be achieved with a dietary concentration of 5 ppm. Similarly, Crome et al. (1996) observed no consistent differences in raising the additional level of 10 to $20 \mathrm{ppm}$. According to Herr et al. (2001a), the current gain of pigs selected for lean meat and feed: gain in lean are more sensitive to lower levels of ractopamine.

Regarding gender, gilts showed $(\mathrm{P}<0.05)$ lower final weight, lower average daily feed intake and better feed: gain than barrows. These results are explained by the lower capacity of voluntary intake of females, higher energy expenditure for maintenance and greater potential for muscle growth (Whittemore, 1986, English et al., 1988).

For the variables of carcass characteristics (Table 4), there was no interaction $(\mathrm{P}>0.05)$ between the addition of ractopamine and gender in these variables. 
Table 4 - Carcass yield, backfat thickness, longissimus muscle area and meat percentage on carcasses of finishing barrows and gilts, fed diets supplemented with ractopamine

\begin{tabular}{|c|c|c|c|c|}
\hline \multirow[t]{2}{*}{ Item } & \multicolumn{3}{|c|}{ Ractopamine level (ppm) } & \multirow[t]{2}{*}{ Mean $^{1}$} \\
\hline & 0 & 5 & 10 & \\
\hline \multicolumn{5}{|c|}{ Carcass yield (\%) } \\
\hline Barrow & 82.54 & 82.08 & 83.08 & 82.57 \\
\hline Gilt & 81.38 & 82.64 & 83.01 & 82.34 \\
\hline Mean 1 & $81.96 b$ & $82.36 \mathrm{ab}$ & $83.05 a$ & 82.45 \\
\hline CV (\%) & 1.59 & & & \\
\hline \multicolumn{5}{|c|}{ Backfat thickness (mm) } \\
\hline Barrow & 25.60 & 22.53 & 21.24 & $23.12 \mathrm{~A}$ \\
\hline Gilt & 21.04 & 16.21 & 17.19 & 18.15B \\
\hline Mean 1 & $23.32 \mathrm{a}$ & 19.37b & $19.21 b$ & 20.63 \\
\hline $\mathrm{CV}(\%)$ & 22.29 & & & \\
\hline \multicolumn{5}{|c|}{$\begin{array}{l}\text { Longissimus muscle } \\
\text { area }\left(\mathrm{cm}^{2}\right)\end{array}$} \\
\hline Barrow & 50.50 & 54.53 & 56.92 & 53.98 \\
\hline Gilt & 49.83 & 51.53 & 64.92 & 55.43 \\
\hline Mean ${ }^{1}$ & $50.17 \mathrm{~b}$ & $53.03 b$ & $60.92 \mathrm{a}$ & 54.71 \\
\hline CV (\%) & 11.76 & & & \\
\hline \multicolumn{5}{|c|}{ Carcass meat percentage $(\%)$} \\
\hline Barrow & 54.10 & 55.64 & 56.69 & $55.47 \mathrm{~B}$ \\
\hline Gilt & 56.40 & 60.13 & 60.11 & $58.88 \mathrm{~A}$ \\
\hline Mean ${ }^{1}$ & $55.25 b$ & $57.88 \mathrm{ab}$ & $58.40 \mathrm{a}$ & 57.18 \\
\hline CV (\%) & 4.98 & & & \\
\hline
\end{tabular}

${ }^{1}$ Means followed by different small letters in the row and capital letters in the column differ by Tukey test $(\mathrm{P}<0.05)$.

Supplementation with $5 \mathrm{ppm}$ of ractopamine was not sufficient enough to increase the carcass yield, the longissimus muscle area or meat percentage. However, pigs fed diets containing $10 \mathrm{ppm}$, in comparison to the control group, showed increases of 1.32, 21.4 and 5.7\% in carcass yield, longissimus muscle area and meat percentage, respectively. These results are similar to those reported by Armstrong et al. (2004), who found that using various levels of ractopamine $(0,5,10$ and $20 \mathrm{ppm})$ in different programs of supplementation $(6,13,20,27$ and 34 days), recommended $10 \mathrm{ppm}$ of ractopamine as the minimum level of response to these variables.

Furthermore, although other authors, such as Silveira et al. (2005) have observed satisfactory results with 5 ppm of ractopamine to heavy pigs (carcass meat percentage $2.63 \%$ more), several studies have shown an increase in the meat percentage with higher levels of ractopamine (ranging from 5 to 10 or $20 \mathrm{ppm}$ ) (Watkins et al., 1990; Elanco, 1999, Herr et al., 2001b, Armstrong et al., 2004), confirming that higher levels of ractopamine can be effective in increasing the amount of lean meat in the carcass as a whole (Schinkel et al., 2001).

The ractopamine, regardless the used level, reduced the backfat thickness of animals by $17.28 \%$. These results are consistent with those reported by Crome et al. (1996), who observed a reduction of $15.7 \%$ in backfat thickness of heavy pigs (125 kg) fed ractopamine. In the same study, the authors also observed that the response to ractopamine by the group of animals slaughtered at $125 \mathrm{~kg}$ was greater than those in the group weighing $107 \mathrm{~kg}$. Mitchel et al. (1990), Mimbs et al. (2005) and Pérez et al. (2006) also reported reductions in backfat thickness in animals under supplementation with ractopamine.

The results in this paper demonstrate the efficiency of ractopamine as a metabolism modifier, increasing the protein deposition rate (increases in longissimus muscle area and carcass meat percentages) and decreasing the fat deposition in the carcass (via a reduction in backfat thickness).

Gilts had better carcass characteristics, with higher meat percentage and lower backfat thickness, regardless the level of ractopamine used. These results were consistent with the best feed:gain presented in the first stage of this experiment. Likewise, results were similar to those observed by Ellis et al. (1996), Leach et al. (1996), Hamilton et al. (2000) and Latorre et al. (2004).

Latorre et al. (2004) studied the effect of sex and slaughter weight on carcass characteristics of heavy pigs, and reported that the influence of hormonal activity, increased basal metabolism, and consumption reduced capacity of females justify these results. Unlike what occurs in other species (sheep and cattle), barrows reach maturity before gilts and therefore deposit more fat in the carcass (Boogs, 1993).

Therefore, the results obtained in this study confirm the possibility of slaughtering heavy pigs without compromising carcass quality, when ractopamine is included in the diet and formulated specifically by gender.

In relation to yield and composition of carcass cuts (Table 5), there was no interaction between the use of ractopamine and gender. The gilts had fat thickness of the belly that was $24.4 \%$ lower than what was found in barrows, and therefore, bellies are $15.2 \%$ more flexible. According to Cantarelli et al. (2008), more flexible bellies may hinder the process of slicing the bacon. Moreover, the carcass tenderloin yield for gilts was $13.6 \%$ higher than the barrows.

These results indicate, similarly to the findings of Whitemore (1986), there is greater efficiency of gilts in depositing lean tissue in the carcass. Unruh et al. (1996) and Latorre et al. (2003) also found a lower yield of lean cuts in barrow carcasses.

There was no effect of ractopamine on the main characteristics of fresh belly, a result similar to the findings of Cantarelli et al. (2008), who, working with 5 ppm of ractopamine for animals slaughtered at $100 \mathrm{~kg}$, also observed no effect of ractopamine on performance and belly flexibility. 
Table 5 - Weight and yield of cuts in finishing barrows and gilts, fed diets supplemented with ractopamine

\begin{tabular}{|c|c|c|c|}
\hline \multirow[t]{2}{*}{ Item } & \multicolumn{2}{|c|}{ Ractopamine level (ppm) } & \multirow[t]{2}{*}{ Mean $^{1}$} \\
\hline & 0 & 10 & \\
\hline
\end{tabular}

Belly yield (\%)

\begin{tabular}{|c|c|c|c|c|}
\hline Barrow & 7.72 & 7.34 & 7.59 & 7.55 \\
\hline Gilt & 7.50 & 6.87 & 7.45 & 7.27 \\
\hline Mean $^{1}$ & 7.61 & 7.10 & 7.52 & 7.41 \\
\hline CV (\%) & 10.40 & & & \\
\hline
\end{tabular}

Fat thickness of belly (mm)

\begin{tabular}{|c|c|c|c|c|}
\hline Barrow & 27.97 & 28.22 & 26.49 & $27.56 \mathrm{~A}$ \\
\hline Gilt & 22.71 & 21.45 & 22.25 & $22.14 \mathrm{~B}$ \\
\hline Mean $^{1}$ & 25.34 & 24.84 & 24.37 & 24.85 \\
\hline CV (\%) & 15.42 & & & \\
\hline \multicolumn{5}{|c|}{ Belly flexibility (cm) } \\
\hline Barrow & 21.65 & 20.10 & 20.40 & $20.72 \mathrm{~A}$ \\
\hline Gilt & 17.90 & 18.10 & 17.95 & $17.98 \mathrm{~B}$ \\
\hline Mean $^{1}$ & 19.78 & 19.10 & 19.18 & 19.35 \\
\hline CV (\%) & 17.08 & & & \\
\hline \multicolumn{5}{|c|}{ Tenderloin yield (\%) } \\
\hline Barrow & 0.929 & 0.983 & 0.983 & 0.969B \\
\hline Gilt & 1.009 & 1.134 & 1.161 & $1.101 \mathrm{~A}$ \\
\hline Mean $^{1}$ & $0.969 b$ & $1.059 \mathrm{a}$ & $1.072 \mathrm{a}$ & 1.033 \\
\hline CV (\%) & 10.41 & & & \\
\hline \multicolumn{5}{|c|}{ Ham yield (\%) } \\
\hline Barrow & 25.43 & 26.37 & 25.69 & 25.83 \\
\hline Gilt & 25.63 & 26.58 & 26.71 & 26.31 \\
\hline Mean $^{1}$ & $25.53 b$ & $26.47 \mathrm{a}$ & $26.20 \mathrm{ab}$ & 26.07 \\
\hline CV (\%) & 3.58 & & & \\
\hline
\end{tabular}

Ham weight $(\mathrm{kg})$

$\begin{array}{lclll}\text { Barrow } & 13.40 & 14.19 & 14.13 & 13.91 \\ \text { Gilt } & 13.23 & 14.14 & 14.29 & 13.89 \\ \text { Mean }^{1} & 13.32 \mathrm{~b} & 14.17 \mathrm{a} & 14.21 \mathrm{a} & 13.90 \\ \text { CV }(\%) & 4.34 & & & \end{array}$

Ham meat percentage (\%)

\begin{tabular}{lclll} 
Barrow & 61.38 & 63.78 & 65.93 & $63.70 \mathrm{~B}$ \\
Gilt & 63.63 & 68.21 & 68.60 & $66.81 \mathrm{~A}$ \\
Mean $^{1}$ & $62.51 \mathrm{~b}$ & $66.00 \mathrm{a}$ & $67.26 \mathrm{a}$ & 65.25 \\
CV (\%) & 4.10 & & & \\
\hline
\end{tabular}

${ }^{1}$ Means followed by different small letters in the row and capital letters in the column differ $(\mathrm{P}<0.05)$ by Tukey test.

The tenderloin yield for animals receiving ractopamine in the diet was $9.7 \%$ higher than the group without ractopamine; a result similar to that obtained by Herr et al. (2001a) and Cantarelli et al. (2008). However, this conflicts with the findings of See et al. (2004).

Animals fed with diets supplemented with ractopamine had observed increases of 3.15\%, 6.3\% and 6.59\% in the ham yield, weight of the ham and the ham meat percentage, respectively. Crome et al. (1996), evaluated the effect of supplementation of ractopamine ( 10 and $20 \mathrm{ppm}$ ) for animals slaughtered at $125 \mathrm{~kg}$, and also observed higher ham yields, with improvements of $2.2 \%$ and $5.54 \%$. Similarly,
Uttaro et al. (1993), Schinckel et al. (2003) and Carr et al. (2005a) reported a higher percentage of meat in ham and other major commercial pork cuts.

The highest cut yields, and at the same time, the higher meat percentages as explained Marchant-Forde et al. (2003) and See et al. (2004), can be explained as a result of the effect of ractopamine in increasing muscle mass and, increasing the diameter of muscle fibers, specifically white and intermediate fibers as observed by Aulhus et. al (1992).

Based on a detailed assessment of the carcass composition held by Cantarelli et al. (2008) and also the results of this study, it can be inferred that the cuts of high commercial value, both for industrialization and for the market of fresh meat have been enhanced with the addition of ractopamine. Thus, it is economically advantageous for the pork production sector to use ractopamine as a feed additive.

Feed supplementation with 5 or $10 \mathrm{ppm}$, compared to diets without ractopamine supplementation, resulted in improved yields and carcass cut composition, except for ham yield, for which the level of $10 \mathrm{ppm}$ showed similar results as the control group. This can be explained by the increase in carcass whole weight provided by this level of ractopamine inclusion, since the ham weight was greater with the use of the additive $(\mathrm{P}<0.05)$, regardless the level used.

There was no interaction $(\mathrm{P}>0.05)$ between gender and ractopamine and no difference was detected $(\mathrm{P}>0.05)$ in the level of the product used ( 5 or $10 \mathrm{ppm}$ ) (Table 6). It was observed that animals fed with diets supplemented with ractopamine had improvements $(\mathrm{P}<0.05)$ in the rate of carcass allowance index (3.62\%), gross earnings (7.29\%), and net earnings (30.94\%), when compared to animals that received no supplementation. This corresponds to an increased carcass value equal to US\$0.16/kg. These results were similar to those obtained by Silveira et al. (2005) who worked with $5 \mathrm{ppm}$ of ractopamine fed to heavy pigs, and observed an increase in carcass value equal to US $\$ 0.17 / \mathrm{kg}$.

Similarly, Cantarelli (2007) observed an increase of $4.88 \%$ in gross earnings and an increase of $17.18 \%$ in net earnings of pigs slaughtered at $100 \mathrm{~kg}$, receiving supplementation with $5 \mathrm{ppm}$ of ractopamine in the diet. However, the author observed a corresponding increase of $2.32 \%$ on the production cost of animals fed with ractopamine.

In gilts, there was reduction in total cost and an increase in carcass allowance index $(\mathrm{P}<0.05)$, resulting in an increase $(P=0.07)$ of $7.68 \%$ in net earnings. These results reflect the effect of gender and the use of ractopamine on animal performance and body composition and serve as a guide for producers to achieve higher production profitability and to meet consumer demands. 
Table 6 - Economic viability of the use of diets supplemented with ractopamine for finishing pigs

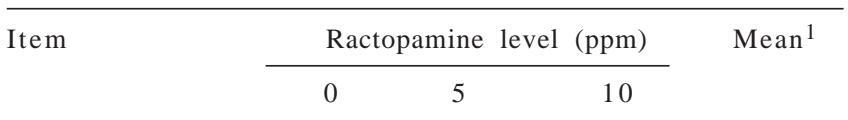

Allowance index (\%)

$\begin{array}{lclll}\text { Barrow } & 107.79 & 110.77 & 111.74 & 110.10 \mathrm{~B} \\ \text { Gilt } & 109.53 & 113.51 & 114.38 & 112.47 \mathrm{~A} \\ \text { Mean }^{1} & 108.66 \mathrm{~b} & 112.14 \mathrm{a} & 113.06 \mathrm{a} & 111.29 \\ \text { CV }(\%) & 2.34 & & & \end{array}$

Crude earnings (US\$)

$\begin{array}{lclll}\text { Barrow } & 219.79 & 236.86 & 238.26 & 231.63 \\ \text { Gilt } & 219.34 & 229.26 & 237.91 & 228.84 \\ \text { Mean }^{1} & 219.56 \mathrm{~b} & 233.06 \mathrm{a} & 238.08 \mathrm{a} & 230.24 \\ \text { CV (\%) } & 3.61 & & & \end{array}$

Total cost (US\$)

$\begin{array}{lrrrl}\text { Barrow } & 192.52 & 193.53 & 194.42 & 193.49 \mathrm{~A} \\ \text { Gilt } & 187.21 & 181.39 & 185.08 & 184.56 \mathrm{~B} \\ \text { Mean }^{1} & 189.86 & 187.46 & 189.75 & 189.02\end{array}$

CV (\%)

2.36

Net earnings (US\$)

\begin{tabular}{lllll} 
Barrow & 27.28 & 43.33 & 43.83 & $38.15 \mathrm{~B}$ \\
Gilt & 32.13 & 47.88 & 52.83 & $44.28 \mathrm{~A}$ \\
Mean $^{1}$ & $29.70 \mathrm{~b}$ & $45.60 \mathrm{a}$ & $48.33 \mathrm{a}$ & 41.49 \\
CV $(\%)$ & 11.79 & & & \\
\hline
\end{tabular}

${ }^{1}$ Means followed by different small letters in the row and capital letters in the column differ $(\mathrm{P}<0.05)$ by Tukey test.

\section{Conclusions}

Supplementation with 5 ppm of ractopamine in diets formulated for barrows or gilts from 94 to $130 \mathrm{~kg}$ is enough to improve animal performance, carcass composition and cut yields. The use of $10 \mathrm{ppm}$ of ractopamine resulted in a greater amount of meat in the carcass, which proves as useful pork producers. Supplementation with 5 or $10 \mathrm{ppm}$ of ractopamine, given the conditions of the study, show that it is economically viable to supplement feed with ractopamine (January, 2008), and that the slaughter of $130 \mathrm{~kg}$ gilts was more profitable than barrows.

\section{Literature Cited}

AALHUS, J.L.; SCHAEFER, A.L.; MURRAY, A.C. et al. The effect of ractopamine on myofibre distribution and morphology and their relation to meat quality in swine. Meat Science, v.31, p.97-409, 1992.

ADEOLA, O.; DARKO, E.A.; HE, P. et al. Manipulation of porcine carcass composition by ractopamine. Journal of Animal Science, v.68, n.11, p.3633-3641, 1990.

ARMSTRONG, T.A.; IVERS, D.J.; WAGNER, J.R. et al. The effect of dietary ractopamine concentration and duration of feeding on growth performance, carcass characteristics, and meat quality of finishing pigs. Journal Animal Science, v.82, p.32453253, 2004.
AROUCA, C.L.C; FONTES, D.O.; BAIÃO, N.C. et al. Níveis de lisina para suínos machos castrados selecionados geneticamente para deposição de carne magra na carcaça, dos 95 aos $122 \mathrm{~kg}$. Ciência e Agrotecnologia, v.31, n.2, p.531-539, 2007.

ASSOCIAÇÃO BRASILEIRA DE CRIADORES DE SUÍNOS - ABCS Método brasileiro de classificação de carcaças. Estrela: 1973. 17p. (Publicação Técnica, 2).

BOOGS, D.L.; MERKEL, R.A. Growth, development, and fattening of meat animals. In: __-_. Live animal carcass evaluation annual selection manual. 4.ed. 1993. p.3-14. (Section, 2).

CANTARELLI, V.S. Ractopamina em rações para suínos em terminação com alimentação à vontade ou restrita. Lavras: Universidade Federal de Lavras, 2007. 108p.

CANTARELLI, V.S.; ZANGERONIMO, M.G.; ALMEIDA, E.C. et al. Qualidade de cortes de suínos recebendo ractopamina na ração em diferentes programas alimentares. Acta Scientiarum Animal Sciences, v.30, n.2, p.165-171, 2008.

CARR, S.N.; IVERS, D.J.; ANDERSON, D.B. et al. The effects of ractopamine hydrochloride on lean carcass yields and pork quality characteristics. Journal of Animal Science, v.83, n.12, p.2886-2893, 2005a.

CARR, S.N.; RINCKER, P.J.; KILLEGER, J. et al. Effects of different cereal grains and ractopamina hydrochloride on performance, carcass characteristics, and fat quality in latefinishing pigs. Journal of Animal Science, v.83, p.223-230, 2005b.

CROME, P.K.; MCKEITH, F.K.; CARR, T.R. et al. Effect of ractopamine on growth performance, carcass composition, and cutting yields of pigs slaughtered at 107 and 125 kilograms. Journal of Animal Science, v.74, n.4, p.709-716, 1996.

DUNSHEA, F.R.; KING, R.H.; CAMPBELL, R.G. et al. Interrelationships between sex and ractopamine on protein and lipid deposition in rapidly growing pigs. Journal of Animal Science, v.71, n.11, p.2919-2930, 1993.

ELANCO. Swine nutrition guide for industry professionals. Indianapolis: Elanco Animal Health, 1999.

ELLIS, M.; WEBB, A.J.; AVERY, P.J. The influence of teminal sire genotype, sex, slaughter weight, feeding regime and slaughterhouse on growth performance and carcass and meat quality in pigs and on the organoleptic properties of fresh pork. Animal Science, v.62, p.521-530, 1996.

ENGESETH, N.J.; LEE, K.O.; BERGEN, W.G. et al. Fatty acid profiles of lipid depots and cholesterol concentration in muscle tissue of finishing pigs fed ractopamine. Journal of Food Science, v.57, p.1060-1062, 1992.

ENGLISH, P.R.; FOWLER, V.R.; BAXTER, S. et al. The basis of efficient systems for the growing-finishing pig. In: The growing and finishing pig: improving efficiency. [S.I.]: Farming, 1988. $555 p$.

GU, Y.; SCHINCKEL, A.P.; FORREST, J.C. et al. Effects of ractopamine, genotype, and growth phase on finishing performance and carcass value in swine: I. Growth performance and carcass merit. Journal of Animal Science, v.69, n.7, p.2685-2693, 1991

GUIDONI, A.L. Melhoria de processos para a tipificação e valorização de carcaças suínas no Brasil. In: CONFERÊNCIA INTERNACIONAL VIRTUAL SOBRE QUALIDADE DE CARNE SUÍNA, 2000, Concórdia. Anais... Concórdia: Embrapa Suínos e Aves, 2000. 14p.

HAMILTON, D.N.; ELLIS, M.; MILLER, K.D. et al. The effect of the halothane and rendement napole genes on carcass and meat quality characteristics of pigs. Journal of Animal Science, v.78, p.2862-2867, 2000.

HENRY, Y.; COLLEAUX, Y.; SEVE, B. Effects of dietary level of lysne and of level and source of protein on food intake, growth performance and plasma aminoacid pattern in the finishing pig. Journal of Animal Science, v.70, n.1, p.188-195, 1992. 
HERR, C.T.; KENDALL, D.C.; SCHINCKEL, A.P. et al. Effect of nutritional level while feeding ractopamine to late-finishing pigs. Journal of Animal Science, v.79, p.73, 2001a. (suppl. 2). (abst.).

HERR, C.T.; HANKINS, S.L.; SCHINCKEL, A.P. et al. Evaluation of three genetic populations of pigs for response to increasing levels of ractopamine. Journal of Animal Science, v.79, p.73, 2001b. (suppl. 2). (abst.).

LATORRE, M.A.; LÁZARO, R.; GRACIA, M.I. et al. Effect of sex and terminal sire genotype on performance, carcass characteristics and meat quality of pigs slaughtered at $117 \mathrm{~kg}$ body weight. Meat Science, v.65, p.1369-1377, 2003.

LATORRE, M.A.; LÁZARO, R.; VALENCIA, D.G. et al. The effects of gender and slaughter weight on the growth performance, carcass traits, and meat quality characteristics of heavy pigs. Journal of Animal Science, v.84, p.526-533, 2004.

LEACH, L.M.; ELLIS, M.; SUTTON, D.S. et al. The growth performance, carcass characteristics, and meat quality of Halothane carrier and negative pigs. Journal of Animal Science, v.74, p.934-943, 1996.

MARCHANT-FORDE, J.N.; LAY JR., D.C.; PAJOR, E.A. et al. The effects of ractopamine on the behavior and physiology of finishing pigs. Journal of Animal Science, v.81, p.416-422, 2003.

MARINHO, P.C.; FONTES, D.O.; SILVA, F.C.O. et al. Efeito da ractopamina e de métodos de formulação de dietas sobre o desempenho e as características de carcaça de suínos machos castrados em terminação. Revista Brasileira de Zootecnia, v.36, n.4, p.1061-1068, 2007 (supl.).

MIMBS, K.J.; PRINGLE, T.D.; AZAIN, M.J. et al. Effects of ractopamine on performance and composition of pigs phenotypically sorted into fat and lean groups. Journal of Animal Science, v.83, p.1361-1369, 2005.

MITCHELL, A.D.; SOLOMON, M.B.; STEELE, N.C. Response of low and high protein select lines of pigs to the feeding of the beta-adrenergic agonist ractopamine (phenethanolamine). Journal of Animal Science, v.68, n.10, p.3226-3232, 1990.

PÉREZ, A.; OBISPO, N.E.; PALMA, J. et al. Efectos de la ractopamina y lisina sobre la deposición de grasa en cerdos seleccionados magros en la fase de engorde. Zootecnia Tropical, v.24, n.4, p.435-455, 2006.

RENTFROWA, G.; SAUBERB, T.E.; ALlEEA, G.L. et al. The influence of diets containing either conventional corn, conventional corn with choice white grease, high oil corn, or high oil high oleic corn on belly/bacon quality. Meat Science, v.64, p.459-466, 2003.

ROSTAGNO, H.S.; ALBINO, L.F.T.; DONZELE, J.L. et al. Tabelas brasileiras para aves e suínos: composição de alimentos e exigências nutricionais. 2.ed. Viçosa, MG: Universidade Federal de Viçosa, 2005. 186p.

SCHINCKEL, A.P.; RICHERT, B.T.; HERR, C.T. et al. Efeitos da ractopamina sobre o crescimento, a composição da carcaça e a qualidade dos suínos. In: CONFERÊNCIA INTERNACIONAL VIRTUAL SOBRE QUALIDADE DE CARNE SUÍNA, 2., 2001,
Concórdia. Anais... Concórdia: Embrapa Suínos e Aves, 2001. (CD-ROM).

SCHINCKEL A.P.; HERR, C.T.; RICHERT, B.T. et al. Ractopamine treatment biases in the prediction of pork carcass composition. Journal of Animal Science, v.81, p.16-28, 2003.

SEE, M.T.; ARMSTRONG, T.A.; WELDON, W.C. Effect of a ractopamine feeding program on growth performance and carcass composition in finishing pigs. Journal of Animal Science, v.82 p.2474-2480, 2004.

SILVEIRA, E.T.F.; ANDRADE, J.C.; MIYAGUSKU, L. et al. The addition of ractopamine to the feed of light and heavy swine and its impacts on meat quantitative characteristics. In: INTERNATIONAL CONGRESS OF MEAT SCIENCE \& TECHNOLOGY, 51., 2005, Baltimore. Anais... Baltimore: ICOMST, 2005. (CD-ROM).

STATISTICAL ANALYSIS SYSTEM - SAS. SAS system for microsoft Windows. Release 6.12. Cary, 1996.

UNRUH, J.A.; FRIESEN, K.G.; STUEWE, S.R. et al. The influence of genotype, sex, and dietary on pork subprimal cut yields and carcass quality of pigs fed to either 104 or 127 kilograms. Journal of Animal Science, v.74, p.1274-1283, 1996.

UTTARO, B.E.; BALL, R.O.; DICK, P. et al. Effect of ractopamine and sex on growth, carcass characteristics, processing yield, and meat quality characteristics of crossbred swine. Journal of Animal Science, v.71, p.2439-2449, 1993.

WATKINS, L.E.; JONES, D.J.; MOWREY, D.H. et al. The effect of various levels of ractopamine hydrochloride on the performance and carcass characteristics of finishing swine. Journal of Animal Science, v.68, p.3588-3595, 1990.

WEBER, T.E.; RICHERT, B.T.; BELURY, M.A. et al. Evaluation of the effects of dietary fat, conjugated linoleic acid, and ractopamine on growth performance, pork quality, and fatty acid profiles in genetically lean gilts. Journal of Animal Science, v.84, p.720-732, 2006.

WHITTEMORE, C.T. An approach to pig growth modeling. Journal of Animal Science, v.63, n.2, p.615-621, 1986.

XIAO, R.J.; XU, Z.R.; CHEN, H.L. Effects of ractopamine at different dietary protein levels on growth performance and carcass characteristics in finishing pigs. Animal Feed Science and Technology, v.79, n.1, p.119-127, 1999.

XIONG, Y.L.; GOWER, M.J.; LI, C. et al. Effect of dietary ractopamine on tenderness and postmortem protein degradation of pork muscle. Meat Science, v.73, p.600-604, 2006.

YEN, J.T.; MERSMANN, H.J.; HILL, D.A. et al. Effects of ractopamine on genetically obese and lean pigs. Journal of Animal Science, v.68 n.11, p.3705-3712, 1990.

ZAGURY, F.T.R. Efeito da ractopamina na ração sobre o crescimento, composição da carcaça e qualidade de carne de suínos. 2002. 46f. Tese (Doutorado em Zootecnia) Universidade Federal de Minas Gerais/Escola de Veterinária, Belo Horizonte, 2002. 